\title{
EMIGRATION OF WLADEK WIŚNIEWSKI AS AN ESCAPE - A REINTERPRETATION OF THE POLISH PEASANT IN EUROPE AND AMERICA VOLUME 3 IN LIGHT OF THE AUTOBIOGRAPHICAL NARRATIVE INTERVIEW METHOD
}

\begin{abstract}
Reading Władek Wiśniewski's autobiography in the third volume of Thomas and Znaniecki's The Polish Peasant in Europe and America, not entirely neglecting the economic factor, it is worth paying attention to a very interesting and not uncommon reason for leaving the homeland, that is "an escape". Its various current modalities can be placed on the continuum between "an escape from" and "an escape to". Using analytical tools developed by Fritz Schütze, which were created much later, but largely inspired by achievements of the Chicago School of Sociology with Thomas and Znaniecki as its major researches, it can be shown that Władek's primary reason for leaving the country was to free himself from tense family relationships. They were based on exploitation and distrust, full of hypocrisy and injustice; a desire to move away from home in order to break with an image of his own identity in the eyes of his Significant Others - as a person who is not worthy of respect, a drunkard and loser. Thus, the main hypothesis of this article (emerging from analysing constellations of events in his life) is: Władek Wiśniewski's motives for leaving the homeland and going overseas are not only and
\end{abstract}

Ph.D., Department of Sociology of Culture, Institute of Sociology Faculty of Economics and Sociology; e-mail: katarzyna.waniek@uni.lodz.pl; https://orcid.org/0000-0002-9468-4479 
primarily economic but are placed between "an escape from" and "an escape to", though they gravitate towards the latter one.

Keywords: The Polish Peasant in Europe and America, migration, escape, linguistically based analysis of autobiography, reinterpretation

\section{INTRODUCTION}

Władek Wiśniewski's autobiography published in the third volume of a monumental work by William I. Thomas and Florian Znaniecki The Polish Peasant in Europe and America [Thomas, Znaniecki 1919 (Polish edition1976), volume $3^{1}$ ] is often regarded as a classic picture of "for-bread emigration" breaking the family ties. However, it is worth looking at it differently and consider if - as in many modern migration careers - a reason for leaving the homeland was a need to free oneself from a biographical trap resulting from difficult family ties and social relationships, lack of mutuality and recognition among the closest ones and consequently, systematically growing alienation from the world of everyday life and a negative attitude towards oneself. This partly alternative interpretation of Władek Wiśniewski's biography (and, above all, of the motives leading to his decision to travel to America) is a result of using techniques and tools for a formal text analysis not available to Thomas and Znaniecki, which were worked out much later by Fritz Schütze and Gerhard Riemann, as part of the autobiographical interview method. It was further developed by Schütze [1981, 1983, 1984, 2008 a, b]. The preliminary analysis of Władek's life process will be a result of looking at it through the prism of - mutually related - sequential analysis, biographical process structures and split coda [Schütze 1987: 167-175, 2008b: 35, 2014: 242-243], i.e.: a protracted argumentative commentary summarizing and evaluating his experiences that reveals his unsolved and nagging biographical problems just before going to America.

However, it must be noted that the following discussion will not be a systematic polemic with many controversial hypotheses of Thomas and Znaniecki showing Władek Wiśniewski as "a typical representative of the culturally passive mass" [Thomas, Znaniecki 1919: 81], or an explanation of his life story only as "an alternation of periods during which he drifts into Bohemianism with periods of Philistinisation, and shows a gradual increase of Philistine tendencies in the total curve of its evolution" [Thomas, Znaniecki 1919: 82]. However, this paper does not discuss the assumption that "every non-creative personality

1 The book was published in five volumes from 1918 to 1920. 
(as, according to the authors, was Władek's personality - KW) is an educational failure" [Thomas, Znaniecki 1919: 82]. Finally, an intriguing issue of the role of elites, which are - thanks to their intellectual virtues as argued by Thomas and Znaniecki - predestined to prevent "the disorganizing effect which the passage from an old to the new form of social organization has upon an individual if not consciously and rationally directed" [Thomas, Znaniecki 1919: 83-84] $]^{2}$ will be ignored. All these issues require a detailed study that considers not only new possibilities of analysing the process of living, socio-cultural transformations and the far-reaching changes within the social sciences themselves (especially in sociology), for which - due to the size of this article - there is not enough space.

To avoid misunderstandings, it must also be emphasized that attempting to read the biography of a Polish immigrant in Chicago anew, Marek Czyżewski's view will be applied. He says:

This is not about questioning the tools used by the creators of the biographical method, nor about questioning the conclusions they have reached, but, on the contrary - it is about expressing recognition and even fascination for, partially forgotten in the meantime, the works of the old masters. Reanalysis is (...) an attempt to formulate a different, complementary or alternative sociological comment to the classic biographical materials collected and originally dealt with at the Chicago school or under its influence [Czyżewski 1992: 95-96].

First, the following reanalysis of the reasons for which Władek Wiśniewski decided to emigrate to America is not an attempt to question the authors' interpretation. Secondly, it is not intended to "defend" or justify - often morally dubious - Władek Wiśniewski's actions, but to show why they happened in the first place (in a specific constellation of biographical and social conditions).

\section{BIOGRAPHICAL PROCESS STRUCTURES AND A SPLIT CODA AS ANALYTICAL TOOLS}

The present re-interpretation of Władek Wiśniewski's biography is an attempt to apply the autobiographical narrative interview method elaborated by Fritz Schütze and Gerhard Riemann. Although this approach was created and developed based on spontaneous life histories told to an interviewer, with some reservations,

2 In accordance with the spirit of their times, Thomas and Znaniecki distinctly emphasize in their conclusions on the records of the immigrants' lives that a planned, rational and conscious reconstruction of society led by thoughtful cultural guides can prevent people of a lower intellectual organization from collapsing morally [Thomas, Znaniecki 1919: 416; Znaniecki 1990]. It is only "under the ongoing influences of the higher classes" [Thomas, Znaniecki 1919: 416] that guarantees a better, if not bright, future for people like Władek. 
it may also be used when studying other personal documents, including written materials [Czyżewski, Rokuszewska-Pawełek 2016/1989-1990, Riemann 2007, Schütze 1980, 2014]. Bearing in mind the preliminary nature of deliberations presented here as well as the length of this article, Władek Wiśniewski's life story will only be studied through the prism of selected elements of the Schütze's approach: firstly, by means of a sequential analysis of the narrative (its segments and suprasegmental compounds ${ }^{3}$ ), which leads to the discovery of the overall organization of the biography emerging from a particular combination of biographical process structures, and, secondly, analysing the split coda closing the main narrative line just before Władek's journey to America (and therefore, in this case, not closing the whole story). After analysing both elements, a conclusion can be drawn that the economic factors were not the primary and most important reasons for his emigration, and that it was rather a feeling of being cheated, betrayed and used by his Significant Others (mainly parents) intertwined at many levels of his experience blocking his path for an autonomous development was decisive in his departure.

Let us take a brief look at the concept of four biographical process structures of the live course proposed by Fritz Schütze and his collaborators - basic forms of biographical experience and an attitude towards one's own life [Schütze 1981, 1983, 1984, 2008a; Prawda 1989; Kaźmierska 2016]. According to the Grounded Theory [Glaser, Strauss 1967], these were identified and described based on their sequential and comparative analysis of many extempore autobiographical narrative interviews and, therefore, was not a conceptual framework worked out "in armchairs", uncritically imposed on improvised life stories.

Accordingly, we deal with institutional expectation patterns, biographical action schemes, trajectories of suffering and biographical metamorphoses.

Institutional expectation patterns (institutional life patterns) reveal a principle of the narrator's orientation towards normative institutional expectations. It refers to life organization and biographical attitudes in which individuals follow scenarios written by their parents or Significant Others and the scripts set by the education system, career paths in various types of institutions, social worlds or their place in a given social system [Schütze 1981: 67-70]. They are expected to adjust their identity to the requirements of institutional models assigned to them.

3 Schütze explains that: "A suprasegmental narrative compound is more than a formulation of a mere event or episode in life (which is dealt with in a narrative unit) or simply a stage in biographical structural processes. It embraces the overall context and course of a structural process, an interplay between two or more of them." [Schütze 1992: 203]. 
Biographical action plans are ways of experiencing events in life that have their source in the inner spontaneity of individuals and relate to the intentional principle of action. This implies taking autonomous long-term plans, independent realization of their desires but sometimes also careful ways of getting out of biographical traps. These are associated with emotional and physical involvement as well as an attitude of vivid expectations towards the future. This comprises their consideration, often consultations with Significant Others or even experts, ratification, implementation, and eventually, evaluation both in terms of their impact on the personal identity and the entire biography.

Biographical metamorphoses are unexpected positive changes in the biography carriers' life, however, despite involving their creative development - they are not always able to handle them, at least initially. Thus, as in biographical action plans - the change has its source in the inner sphere of the spontaneity of an individual, similarly to the trajectory of suffering (described below) - it unexpectedly introduces disorder and a sense of self-alienation into the individual's life. The change is often associated with a sense of overpowering, an intriguing mystery, the impossibility of dealing with a surprising definition of oneself and the inability to find categories to describe their experiences.

The trajectory of suffering means a systematic "erosion of social and biographical order" [Treichel, Schwelling 2003: 131]; all these experiences in which people realize the fragility of the everyday world of existence and have a sense of losing control over their lives. Individuals affected by suffering note with fear that they are no longer able to control or predict their reactions. Therefore, they are overtaken by a paralyzing conviction that they have been caught in a trap with no way out and start to react passively to overwhelming external circumstances. This is accompanied by a deepening and irritating sense of "separation from the outer world of normal existence" [Riemann, Schütze 1991: 343], extreme isolation, loss of meaning, frustration and bitterness. What is important, this is exactly the moment when they need help the most, especially from their Significant Others, but growing communication barriers drastically reduce or even block it [Riemann, Schütze 1991: 352] $]^{4}$. However, it must be remembered that, firstly,

4 Paradoxically, the process of increasing disorder has its systematic arrangement and usually takes place in the following sequence: (1) accumulation of the trajectory potential, (2) sudden crossing of the boundary between an intentional action and passive reaction, (3) attempts to develop and maintain a state of precarious balance, (4) destabilization of that state, (5) breakup of everyday life organization and self-orientation, (6) attempts to theoretically come to terms with the trajectory, and (7) practical work upon the trajectory and gaining control over it or escaping it [Riemann, Schütze 1991; Schütze 2012]. 
all process structures appear not in all life histories, and, secondly, that in each biography they create various configurations (specific for a given case). These may not only follow one another but also compete with one another, mutually reinforce, weaken, accelerate, delay or even annihilate one another; finally, these can have a dominant, stabilizing or recessive character. These combinations of biographical processes and their repositioning in the framework of social, cultural and political processes allow us to indicate both unique features of a given life history and typical (i.e. common to many cases) properties of a process and thus enable to reconstruct an overall organization of the narrator's biography.

Another important element of the autobiographical narrative interview method, in the light of which motivations of Władek's emigration may acquire another meaning, is an expanded pre-coda that takes the form of a split coda. It constitutes the closing of the main narrative story that consists of two elements: a summary and evaluation of the whole stream of life experiences (a kind of "biographical reckoning") and a transition to the present life situation (in the case of autobiographical interview it reaches «here and now», the current communication situation of the interview [Schütze 1987: 167-175; Schütze 2008a: 19-20, Labov, Waletzky 1967; Labov 1972]. However, it often occurs (and then we deal with an expanded or split coda) that theoretical-argumentative commentaries about the whole experience become very long. It happens when people are unable to give meaning to their past experiences, but - being aware that their recollections are expressed in the presence of a listening person or a potential (imagined) reader - they must unexpectedly cope with evaluating their biography and unresolved problems. It is usually a very strong marker that the narrator has undergone or is experiencing the trajectory of suffering that has not been dealt with yet, and he/she is in a difficult position in terms of his/her personal identity and biographical development [Schütze 2014: 243 and footnote 13].

Sequential analysis of Władek's autobiography, which takes into consideration his way of experiencing life events reflected in the manner of their text presentation $^{5}$ and comments explaining his decision to emigrate to America contained in a split coda, provides empirical evidence that Władek Wiśniewski constantly desired to get out of the trap which was his parents' repressive and discriminatory institutional normative model, while the "last straw" had been their plan to run a bakery together and its eventual failure. As a result, he was systematically yet unsuccessfully attempting to free himself from expectations of his family

5 Fritz Schütze's approach makes us constantly link what is said with how it is said. In other words, analysing autobiographical renderings we must always consider formal features of the text. 
(especially his parents" - what "mother had planned"), their aspirations and ambitions (most probably related to their middle-class position) concerning his forced choice of career, unjust liabilities, and a hypocritical system of values (also among bakers, whose corporation became more and more immersed in anomie), imposed images determining social position and possessions of his future wife, or finally, from discrediting features assigned to him. Let us look at this interpretation in detail.

\section{EMIGRATION OF WLADEK WIŚNIEWSKI AS AN ESCAPE}

Analysing Władek Wiśniewski's life record one should remember that he was not a typical poor peasant ${ }^{6}$ who boarded the ship to America in search of easy money, thanks to which he could fill his "still Polish" stomach shrunken because of hunger ${ }^{7}$. From the last pages of his diary (paid for by Znaniecki), it appears that it was in the receiving society that Wiśniewski began to live from hand to mouth, it was there that his economic situation was becoming hopeless, even disastrous (at least till he ended his recollections). On the last page of his autobiographical record, he writes: "It would be really better if I had died long ago, for I have no hope for getting work" [Thomas, Znaniecki 1919: 399]. Then he explains: "It is awfully difficult to get work without protection, because of the terrible crisis brought by the European war..." [Thomas, Znaniecki 1919: 399]. And he

\footnotetext{
${ }_{6}$ Thomas and Znaniecki realize, though not always, that: "Władek and his family are of peasant origin and often in touch with peasants, but no longer belong to a peasant community. Some Władek's relatives and Władek himself live in towns and mix there with the lower city class - small merchants and hand workers - but the family is not originally a part of any of the old lower town-communities, which were formerly as close and traditional groups as the peasants of a farmer-community. No definite social place can be assigned to the Wiśniewskis in the old class-system; in the new class-system they certainly belong to the intermediary class between the unskilled workmen and the lower-middle class" [Thomas, Znaniecki 1919: 83].

7 The contrast that Władek draws between himself and the passengers of a ship sailing to America may support it. He writes: "O God! have a pity upon these poor people who through their own will, through persuasion, through necessity leave their country, their parents, wives and children. With what regret many of them were leaving their parents, wives, children, the farm houses in which they and their fathers saw Thy light! And they left in order to improve their existence, to earn some roubles and to come back to all that which they had left..." [Thomas, Znaniecki 1919: 384]. He also adds a common-sense diagnosis (referring to the socio-political context) of their situation: It is true that they are dark and uninstructed, but even, therefore, they have not a king, a father of their own, who would try to educate his children. They have step-fathers, not one, but three tyrants who hold their step-children in a hard slavery... This slavery, this lack of understanding of life, divests them of shame and ambition" [Thomas, Znaniecki 1919: 384-385].
} 
adds: "I cannot even now take a walk with my wife, for she has not even shoes to put on her feet, but she wears my old shoes." [Thomas, Znaniecki 1919: 399]. With a great dose of precaution (because this lamentation could be a rhetorical technique aimed at increasing Znaniecki's generosity $)^{8}$, it can most probably be stated that for Wiśniewski - in accordance with the letter sent from Chicago in July 1928 to his brother Lucek (three years before his death) - "the poverty in the homeland was better than the American one" [Jakubczak 1976: 316].

But we already know that Władek did not leave Poland to get a better life in the economic dimension, but - and this motivation seems the most important one-he escaped to America from the feeling of being "black sheep" in the family. Unwanted, undesirable, "the laughing stock of his family" [Thomas, Znaniecki 1919: 377], bringing shame, a rejected member of the Wiśniewskis family. It can be assumed that this is how Znaniecki and Thomas treated the autobiography written by Wiśniewski, at least partly. Similar themes can also be found in the work of Krystyna Duda-Dziewierz: "Polish Village and American Emigration" published in 1938 or in Adam Walaszek's work: "Migrations of Europeans 1659-1914" published in 2007. The latter writes, inter alia, that the "Biography of Wisniewski can be an illustration of the thesis that migration, in addition to other accompanying circumstances, was often an act of fighting against fate and a rebellion against the way of life, supervision of the elders and the family" [Walaszek 2007: 156]. This motivation can also be seen in an image of symbolic elites of that time: for example, as Walaszek mentions, priests worried about a huge migration of young people from the countryside (to America). They talked about it as about an obvious need for freedom, a desire to escape the supervision of the elders and pressure of the environment [see: Walaszek 2007: 156] ${ }^{9}$. It is not a new discovery that emigration considered only as an attempt to improve material living conditions is an incomplete picture of migration processes, and thereby simplifies and obscures motivations for long-term overseas trips as well as biographical consequences of such choices [see: Urbańska 2015].

\footnotetext{
The need for money made Władek Wiśniewski write his diary quickly. Therefore, it can be assumed that his written life history is at least partially spontaneous, which additionally (due to his haste) was not subjected to his thorough corrective and editorial procedures. This brings his diary closer to the extempore oral autobiographical accounts and allows the procedure of analysis developed by Schütze to be used in a wider range.

9 Walaszek refers to: 12th Deans Congress in 1907, Archives of the Metropolitan Curia, Raków, Refugees folder, p. 25 [see: Walaszek 2007: 156, footnote 99].
} 
It is worth looking at the findings of "Euro Identities" ${ }^{10}$ here. This international project has gathered a very rich collection of autobiographical narrative interviews with people who were learning or studying abroad for a long time, but also with people who have married or have been in partnership relations with foreigners, or finally, with culture creators or members of non-governmental organizations, whose activities go beyond the borders of their native countries. The analysis of the obtained empirical data revealed, among others, various constellations of biographical and migration experiences of narrators and their place in different socio-cultural contexts (understanding and giving meaning to their biographies), and showed that in many cases leaving the country is not primarily motivated by economic reasons or willingness to gain new experiences, but by the need to escape. It takes on different forms and has different dynamics, and thus may extend on the continuum from an absolute compulsion and dominance of pushing mechanisms (such as a sense of emotional, social or economic deprivation) to a vague desire to run away from the restrictive home; from the point of view of an individual, it is a possibility of (full) implementation of his/her biographical plans and development of his/her own identity. This first extremity refers to the category "an escape from" and the other one "an escape to" [Kaźmierska et al. 2011; Waniek 2015] $]^{11}$.

A whole spectrum of biographical experiences can be found within this range, in which the escape process will approach one extremity and the other another time, it will interweave with other process structures (subordinating them to itself, existing simultaneously, strengthening them or destroying them completely). Although it is difficult to distinguish clearly and precisely these escape modes, they can be depicted as follows: an impulse to "an escape from" is a subjective definition of one's own life situation as systematically out of control over the primacy of external circumstances, anxiety and growing disorder in the world of everyday existence. The inevitable consequence of this experience is crossing the border between intentional action and "blind automatism" [Riemann, Schütze 1991: 352]. Therefore, the choice of the place where an individual finds shelter is made by chance or fate rather than intentional, "rational" planning of his/her own biography. In other words, it is such a biographical situation in which an individual makes an almost desperate attempt to escape the destructive influence

10 The project was implemented as part of the 7th Research Framework Program of the European Commission by research teams in Northern Ireland, Bulgaria, Estonia, Germany, Great Britain, Italy and Poland. See: Waniek [2011], Miller, Gray (eds.) [2012].

11 This distinction is inspired by reflections of Erich Fromm from the book "Escape from Freedom" and the concepts of "freedom from" and "freedom to". 
of the dynamics of trajectory processes in its peak phases. On the other hand, in the case of "an escape to", we can see elements of conscious planning and consideration of possible alternative paths of self-realization and prudent choice of the destination. Therefore, it is more related to opportunity structures (meaning that an individual does not escape wherever), which allows moving away from institutional patterns of the biography perceived as too restrictive than the logic of randomness. In this case, families, peer groups, local environment, and even a national community are defined as external forces limiting the full freedom of individual actions or thwarting any attempts to "spread the wings". Then internal states stemming from a sense of boredom with a lifestyle start prevailing, further strengthened by suppression or lack of satisfaction and fulfilment.

Biography incumbents often talk about their emotional deficiencies, disregarding their will and views, about lack of honesty and openness in interpersonal relations, and about superficial morality of their Significant Others, which introduces disorder in interpersonal relations and considerably disturbs trust in the world [Kaźmierska et al. 2011, see: also Urbańska 2015, Waniek 2015]. This usually results in their feeling of being a misfit, not fitting the family or milieu, and sometimes even being stigmatized or excluded ${ }^{12}$. In other words, we deal here with a configuration of the biographical action plan of action and (early) stages of the trajectory process emerging from institutional patterns of expectations that limit or block self-realization.

Let us return to the analysis of life circumstances and subjective assessment of his own situation, which led Władek Wiśniewski to leave his homeland and go to America. The processual analysis of his biography shows that his life experiences fit this continuum and gravitate towards "an escape to". This is - using Thomas and Znaniecki's words [1919: 37] - a variant of personal evolution that - as they both emphasize - "is always a struggle between the individual and society - a struggle for self-expression on the part of the individual, for his subjection on the part of the society - not a static "essence" but a dynamic, continually evolving set of activities - manifests and contrasts itself." [Thomas, Znaniecki 1919: 37-36]. First, let us focus on the earliest memories. It is nothing new to say that the "biographical background" of childhood and adolescence is usually of key importance for understanding an individual biography [see: Rosenthal 2012]. As Daniel Bertaux puts it: "the level of permanent relationships with parents and

12 It is worth noting that in the case of "an escape to ..." mere imagining potential negative actions of the Others (such as persecution or rejection) or imagining consequences of the revealed otherness can become a stimulus to leave the current living environment [see: Goffman 1990a]. 
relatives" [2012: 312] is significant here. Thomas and Znaniecki seem to have a similar approach to Władek's evolution (treated here as development of personal identity) arguing that it should be considered in the light of his specific social position and not only "in particular social conditions in which he evolved", but also "numerous elements whose significance reaches far beyond his milieu and his time" [Thomas, Znaniecki 1919: 85]. However - unlike the classics - we will no longer treat these contexts as permanent dispositions shaping his values and ways of experiencing the world, but as a stock of knowledge at hand and interpretative patterns allowing to negotiate the definition of the situation and identity of interaction partners (including one's own) in the interactive process.

Looking at "what" and "how"13 Władek Wiśniewski writes about his childhood, we will quickly realize that his parents' lifestyle and way of raising children were at least partially intended to make an impression [Goffman 1990b], which aimed at upgrading and/or strengthening their position in the social hierarchy they subjectively conceived. It was extremely important to them, because - as we might think - they were still "hung" between the peasantry and the middle class. Let us have a closer look, for example, at several descriptions of parents' practices mentioned at the beginning of Władek's autobiography. He writes:

We were always dressed cleanly and neatly, and everybody envied us. It was a habit of my parents to dress us up twice a year at Christmas and at Easter. We then had everything new from head to toe - at Christmas, boots, overcoats, caps and suits; at Easter, hats, shoes and summer-suits. It was always if I was at home, and about this, my parents did not quarrel. When we were dressed like this and went to church with our parents, people stopped and looked at us, saying: "Where does their father get money for all this? [Thomas, Znaniecki 1919: 97].

This short excerpt makes it obvious, that in the perception of the author of the diary, these clean and neat clothes were to arouse jealousy and admiration of other people, and not express the parents' concern for their children. The kids, in turn, gained in their eyes, when they were obedient, just "to show off", as in the case of the eldest brother Aleks, who gave money to a blind man and - at his father's request - walked him to the other side of the city [see: Thomas, Znaniecki 1919: 96] arousing general admiration among its inhabitants, who did not spare their father praise for raising such an obedient son. Later Władek recalls that "my parents had respect and consideration from people who considered them rich;

13 This is the distinction Ingeborg Helling makes between a biography as a means and a biography as a topic, in which the researcher is respectively interested in "what?" becomes the subject of the life story and "how?" - meaning what the formal structure of individual utterances looks like [Helling 1990: 16]. 
and really my parents behave like well-to-do people [see: Thomas, Znaniecki 1919: 98], clearly implying that it was about making a systematic impression rather than their real social position. In other words: they gained the admiration of others, not because of their actual holdings, but because they "behave like well-to-do people". Numerous parties that were held on New Year's Eve, after Easter, or on name days [Thomas, Znaniecki 1919: 98-103] certainly helped it.

The thing is, however, that Władek was aware of the superficiality of this behaviour and (perhaps because of this) he was not an obedient child who, like his elder brothers, would fulfil the expectations of his parents without questioning. He had, as it may be assumed, a special ability to see an irritating illusion and mercenary game in the behaviour of interaction partners ${ }^{14}$, which "under the disguise of" social norms allowed bad or even immoral behaviour: e.g., the principle of "obedience to parents" gave them an opportunity to take money from him - from a common bakery. This made him (especially in the eyes of his parents) a difficult child, unable to adapt, unruly, vain, self-centred, vengeful, envious, the one who they did not know what to do with. In other words, his "me"-images - that allow people to look at real-life situations from the perspective of existing or imagined others [Mead 1934] were almost always negative, always required reprimand and special treatment. Thus, his memories of childhood and early youth are actually an account of a systematic and growing rejection by the family - especially by his mother - who, in his subjective perception: when he was eight years old "loved (him) at least a little", although - despite his strenuous efforts to beg for love - he was always unkind, there were always reasons to be punished and rejected by her ${ }^{15}$. Władek writes:

It often happened that when my turn came to pasture the geese in the afternoon I remained long after everybody had driven everything from the field, having intentionally driven my geese into some hiding-place in order that they might not find me. Sometimes one of the older children or a mother came to look for me. If it was a mother, I showed myself soon for, as I said, I loved my mother more than my life. Sometimes, when mother brought afternoon lunch to me in the field, she told me to put my head upon her knees, and then, O my God, it was one of the happiest days of my life. Then her fingers went through my hair as if they sought something, but as there was nothing to seek, for my head was always clean, it was from love only. Then I thought that my mother loved me at least a little. This affected me strongly and I was ready to kill myself for a single warmer embrace from my mother. But my brothers and sisters, who did not care much for it, received more and I was very jealous.

14 Unfortunately, Thomas and Znaniecki saw in Władek only "a theatrical attitude, a strong cabotinism" [Thomas, Znaniecki 1919: 408].

15 Thomas and Znaniecki interpret Władek's desire for mother's love only as the seed of the Freudian Oedipus complex [Thomas, Znaniecki 1919: 104, footnote 2]. 
I always brought my mother a nosegay of field flowers, or a few water lilies, which grew in some of the ponds, or peas in pods, or a pear; if I ever received two, the better one was surely destined for my mother. But all this did not help; I was always good for nothing, there was always some reason for rebuking me and pushing me away from her. Despite this, I always loved my mother, and the bigger I grew the more I loved her. I did not love my father even half as much as her; in every situation, mother was the better. When I drove the geese into the field, she always gave me something [to eat]. [Thomas, Znaniecki1919: 103-104].

From current perspective, one could look at his behaviour as a kind of "cry for help" - even a humiliating begging for "one gracious hug" in the situation of basic expectations and a sense of deprivation, though Thomas and Znaniecki recognized them as a vain desire for feedback and a need to effect his social environment [see: Thomas, Znaniecki 1919: 408]. Reading this passage, but also referring to the whole life history written down by him, one can get the impression that Władek was the only child treated with no respect to basic rules of family behaviour based on mutuality, solidarity, loyalty and trust. He was just another pair of hands to work or bring money. And Thomas and Znaniecki find a typical - adopted from common sense social psychology - explanation for it: "almost every family of this class selects one child to be worst treated, least loved and most exploited." [Thomas, Znaniecki 1919: 410]. However, considering the organisation of his experiences, it becomes clear, that it was then, that the sense of mutual suspicion grew systematically, and he began to be defined as an untrustworthy loser.

The whole experience of Władek Wiśniewski is in fact, as Andrzej Piotrowski remarks accurately "a drift - a repetition of trajectory cycles" [2018]. All his efforts to gain and consolidate his life balance (by fulfilling expectations set by the institutional normative model), or to gain independence and autonomy (to introduce his biographical action plan) failed - he himself disturbed or was forced to end them. Disregarding many details and stages of his life course, let us take a closer look at his baker apprenticeship. It is interesting that - as Władek writes - when he was fourteen his father and his mother began to mention a need to learn a trade - they gave him freedom of choice. Thomas and Znaniecki understand this freedom to decide as a lack of interest in his future, and they contrast the parents' attitude towards Władek to the carefully planned future for his elder brother Stach. This independence in decision making, however, had an apparent character: a few pages further, Władek mentions that his mother was in fact disappointed with his plan to be a baker and preferred him to become a butcher, to follow his father's suit [Thomas, Znaniecki 1919: 118]. It should also be noted that Władek's decision was not motivated by an internal spontaneity, his own intention, his love for baking bread, but it was dictated by a rather 
practical attitude and the necessity of adjusting himself to external expectations. Perhaps this also accounts for Władek's absences during his apprenticeship. First, contrary to the biographical action plan, failures to implement the institutional expectation pattern usually discourage further action, consolidate a conviction about the senselessness of undertaken steps and deepen a lack of self-confidence. Secondly, imposed forms of realisation on one's own biography are associated with a negative attitude and shortage of emotional involvement. This usually makes it impossible to achieve the required level of skill or craft.

The above explanations provide the basis for a critical assessment of Władek's sister-Florentyna, who calls him "a lazy fellow", "accustomed to running away" [Thomas, Znaniecki 1919: 123]. She presented the opinion of the whole family and, to a large extent, also of Thomas and Znaniecki. Yet a sequential analysis of his written narrative about the events in his life and his ways of justifying decisions he made shows that Władek did not give up working in the bakery because he got bored or did not feel like working there any longer. He left the first apprenticeship because he could not bear the violence and drunkenness of his employer, Mr D., who beat his apprentice Janek so hard that "instead of making a man out of him and inculcating good principles in him drains his health and strength once and forever" [Thomas, Znaniecki 1919: 125]. This experience led Władek to undertake a desperate attempt to free himself from misery by cutting off his finger. However, he gave up on this idea because "he lacked courage" [Thomas, Znaniecki 1919: 127 $]^{16}$. With tears in his eyes, he was reflecting on his bad fortune and the injustice of his parents, who were "so cruel and merciless" [Thomas, Znaniecki 1919: 126] to him, though they could do much for his brother, Stanisław. After a year and a half, he quit his apprenticeship at Mr. W.'s in Turek, who "almost never came to the bakery, but drank and drank, ceaselessly" [Thomas, Znaniecki 1919: 135]. It happened when he informed Mr. W. that his apprentices had thrown away the badly prepared dough made from four bags of flour into the river, but they denied everything and Władek was called a liar. In Sosnowiec, in turn, at Mr. K.'s, an elderly man, things were going well until his son took over the bakery. Then he writes: "the true hell opened before me (...) because he abused not only me but his own mother" [Thomas, Znaniecki 1919: 150]. He was probably

16 Thomas and Znaniecki comment on this event as "typical for a weak person" or (rather common among women) hysteria [1919: 126; footnote 2]. They do not consider that these experiences could have been a trap and an overwhelming misfortune for such a young man. Quitting the apprenticeship was associated with social (breaking the contract) and financial consequences (paying for being freed from the apprenticeship obligation), which his strict father had to suffer at the time. 
a madman who, in an upsurge of anger, called everyone names, destroyed badly prepared bakery products - and made Władek eat them soaked in water. Next, he did not like the work at Mr. Józef's in Sosnowiec, because the owner "drank continually and there was no money to buy flour" [Thomas, Znaniecki 1919: 180]. However, he quit it only when the owner returned drunk from the village and began to "abuse his wife violently, and she did not fail to call him names in return (...) brought to a still grater wrath, slapped his wife rather heavily on the cheek and went back to the joint" [Thomas, Znaniecki 1919: 180-181]. For Władek it was the first time he saw a man beating his wife. He also resigned from working in a Jewish bakery when he realized that he wasted all the money drinking with his colleagues and "began to be like a brute" [Thomas, Znaniecki 1919: 185]. In the meantime, he visited Grodno, Vilnius and Kaunas and then after a long time of looking for a job in Łódź he finally managed to find a job but had to quit soon. The reason for this was that he hit Stefan, an always sleepy baker's helper, and damaged his ear membrane. Consequently, he was supposed to pay for his treatment, but he was not able to afford it. The alternative was a prison sentence. His boss advised him to flee [see: Thomas, Znaniecki 1919: 240-241]. Władek comments on his life situation as follows:

But what could I do, poor fellow? Remain and sit in prison? This did not please me, for I had never been in prison. No, this was not good either; I preferred to wander. And again, I began to curse this dear baker's work. For what shall I come to? I thought. Perhaps I should be obliged to tremor thus about the world during my whole life. Really, if I had had a bottle of vodka at this moment, I would have drunk like a swine in order to forget my situation at least for a moment. [Thomas, Znaniecki 1919: 241].

A sense of loss of meaning and hope that prevails in his narrative, resulting from getting stuck in a dead-end which was a baker's career is a clear indication of the dynamics of the process of the trajectory of suffering and losing control. Looking further into his story, we will see that for some time he was convinced that he was doomed and that there was no way to change it. He writes about his misfortune:

For really, I had reason enough to cry, thinking about myself and my family. No one of my family even knew how much I had suffered since Pentecost, how much hunger and cold I had borne, while they were sitting in warm rooms and well-fed. But what do they care, even relatives, if their own brother suffers there, in the far world, hunger and misery, provided they don't feel it themselves? [Thomas, Znaniecki 1919: 241].

It is clear in this piece that Władek was "excluded" from his family, deprived of support and interest of his relatives. This was accompanied by a feeling of injustice and a deepening sense of alienation present throughout his life record. 
Not knowing what to do, he decided to return to his parents. The situation was unusual because he had avoided such a solution before that time. It was Christmas Eve, and perhaps that was the cause why he did not look for shelter elsewhere. When he arrived home, he looked through the window and saw the whole family sitting at the table and he lost consciousness while watching them with tears in his eyes. This physiological reaction probably had its source in physical and emotional exhaustion. When he came around, he knocked on the door and although he was welcomed with hospitality and well treated, he set off on a further journey the next day. Having experienced the hardships of wandering he got a job at Mr. Krasowski's, but he did not manage to keep it for long, either. He was irritated by the fact that the employer made his apprentices work all the time, who were not able to see to the bakery due to sleep deprivation and for which they were severely punished and called names [Thomas, Znaniecki 1919: 266].

Between the places of his apprenticeship described here, Władek travelled from a city to city seeking a job, often lived in poverty, and sometimes visited his siblings and made numerous acquaintances with girls. Finally, out of despair, he joined the army and then became a policeman. These excerpts of his narrative, however, due to the size of the text, will be omitted here, except for one comment, which Władek made referring to the end of his military service. When everyone was happy to return home, he could not sleep, for he was the only one who did not know "where and for what should he return?" [Thomas, Znaniecki 1919: 323]. He explains: "I wanted to remain anywhere in order not to return to my village, and particularly to my family, for my own father wrote me to try to find a place: "You know, dear son, that there is no home waiting for you, and again you will be forced to wander" [Thomas, Znaniecki 1919: 323]. Interestingly, Thomas and Znaniecki comment on this statement as follows: "He dreads the return to a milieu which subjects him to certain obligations, however limited, especially since his disorganization by the Prussian trip and the army." [Thomas, Znaniecki 1919: 323; footnote 1]. But an alternative interpretation would be that he does not want to return to the environment in which he is unwelcome and defined as a troublemaker. What is more, in the view of all Władek's experience, which - as it is demonstrated - shows the dynamics of an escape process, Thomas and Znaniecki's explanation seems even more questionable. One of the key features of this process is such attitude to life, in which one does everything not to go back home or to leave it as quickly as possible and despite piling difficulties. We could already see numerous examples of such behaviour in his autobiographical 
rendering, for instance, when, after the Christmas Eve supper, before which he had fainted in front of his family house, he immediately set out on a journey. What is more, the letter from his father was not an expression of his willingness to take him home, provided he found a job, but a clear refusal to support him. In other words, we deal here with a violation of the principle of mutuality, which is basic for the social order, which is about helping a person (especially a close one) in a critical position [Schütze 2012: 430,445], which is an obligation of the Significant Others, in particular. However, this did not happen, and not for the first time Władek was rejected by his family and left alone in dramatic life circumstances, which strengthened his conviction that he could not trust anyone nor count on anyone.

The proposal made to Władek by his brother Paweł to set up a bakery together with their father and mother could be a possible way out of this increasingly worsening situation resembling going down a slippery slope. This idea appealed to Władek because he immediately began to put it into practice: he happily informed his parents about his intentions, gave up his work at the police, started to look for a suitable place. When he finally found it, he cheerfully initiated the construction of the stove and did not spare money so that the priest would "tell people from the pulpit to patronize my bakery and not to get bread from a Jew or a man of another nationality" [Thomas, Znaniecki 1919: 345]. An optimistic mood accompanying these plans, a conviction about a possibility of creating something of his own, obtaining a certain degree of autonomy are characteristic of an emergence of a biographical action plan. But this initiative was to be killed soon. Although the bakery functioned quite well, Władek did not get a lot of profits from this family business, and in addition, as he writes: "I was not even permitted to call myself the proprietor of the bakery, for father took the whole management upon himself and had me as a journeyman. But he did not pay me like a journeyman. I had to beg my parents for every grosz or else to steal it (...)" [Thomas, Znaniecki 1919: 346]. Meanwhile, Władek's parents and siblings used the bakery funds freely and they had a great time. His hopes of regaining independence, unrestrained action and an opportunity to spend the money he had earned failed. He had a feeling of being trapped again. The only way out he could think of at that time was a marriage to a well-to-do maiden. But interferences of his parents were significant here as well - they sneered unceremoniously at his choices.

It seems that these endless attempts to restore meaning and order in life interwoven with periods of loss of control over his own life were extremely frustrating and exhausting to Władek. In this light, his trip to America can be 
regarded as an escape from accumulating trajectory potential or a cumulating disorder [Schütze 2012: 429].

The way Władek concludes the "Polish" part of his life history is another empirical evidence for that.

\section{A SPLIT CODA - AN ATTEMPT TO CLOSE AND EVALUATE HIS OWN LIFE BEFORE GOING TO AMERICA}

Let us look at how an opportunity of going to America appeared in Władek's life and how he explains his decision to go overseas to his family in the context of these short and brief analyses of the fragments of Władek's recollections.

When Władek was sure that his parents defrauded money from their joint bakery, he simply felt cheated by them and experienced a total degradation, he received a letter from his sister Maria, who had been living in Chicago for some time. She offered 100 roubles to one of her friends who would decide to come to her. Władek immediately decided to go for it, asking her almost the same day [Thomas, Znaniecki 1919: 377] to send this money to him, her brother. She did so and he began his preparations for the journey just before Easter. Shortly afterwards, he received an invitation from his brother Pawel to spend Easter with him in Łódź so that they could say goodbye to each other. They were celebrating in rich and "impressive" apartments that belonged to his boss. When they went to Pawel's house, he and his younger brothers, Ludwik and Roman and his sister-in-law begged him not to go to America. Władek describes this situation as follows: ,[they] moved me so much that I began crying. I stood up from the chair, walked about the room..." [Thomas, Znaniecki 1919: 377]. Then he vividly reproduces his monologue:

My dear ones! I regret much to leave my whole family and I don't know whether I shall come back and see anybody of my family, but I prefer to die there far away, even in misery, rather than remain the laughing stock of my family. You know best, my Pawel, what I have experienced here! You as well as the others were ashamed of me when I was in Łódź. Wait, don't interrupt me. I don't consider that it was bad of you, for there were enough reasons to be ashamed; I was ashamed of myself. But this is in the past. Then I was a constable and I have letters in which I was laughed at. But this is also past, and with your help, I put some roubles aside and established a bakery in the company of my parents. Now, after two years of my labour and of my endeavours, what is left for me? Either to go again tramping or to marry, even a goat if it has money ' [words from a song]. For my parents don't care. They tell me that I have spent this money long ago in drinking, eating and smoking; they simply drive me away from my own property. And this is not enough! They compromise me before girls whom I like in order that I may be rejected, for they like it as it is now; they have a journeyman in me and treat me as such. And you see the profit I have from my bakery. I have not a copeck. To come here I took some of the money which was for the journey to America. I owe you 
50 roubles and cannot give you back even a copeck. But this is not all. They require at least 200 roubles when I marry. And what for all this? Have I cost my parents anything? Have they spent money on me? It is a duty to help one's parents, but not to give one's last shirt and to remain naked. [Family robs the common fund etc.] Here you have my reasons for going away, clearly exposed. I have nothing to regret. Perhaps there, beyond the pond, I shall earn enough for my own bakery. Then I will come back, and if I don't earn, I won't come [Thomas, Znaniecki 1919: 377-378].

According to the autobiographical narrative method in the understanding of Fritz Schütze, we deal here with a kind of coda which summarizes and concludes the narrator's previous life, which, although it does not take place at the end of the story, closes the previous and dominating period of the author's life. A small comment seems necessary here: the meaning of this statement as "closing and evaluating" the life of the narrator should be assessed from the perspective of the entire presented life story. In the first American edition published in 1919, the immigrant's life record is printed on pages 89-400. The letter from his sister Maria appears on page 376 (the first time he mentions going overseas), the fragment quoted above is on pages 377-378, and the journey to America is described on pages 383-385. The key immigration experience takes no more than the last 16 pages (from page 385 to page 400$)^{17}$. In other words, what happened before Władek's journey overseas significantly prevails in his autobiographical rendering, and this makes it possible for us to treat the quoted fragment as a kind of coda. However, coming back to Władek's story we should pay attention to the form that this coda takes. Referring to Schütze's approach - we deal here with a cognitive figure of scenic social situations [Schütze 2008a: 38]. Its basic marker is direct speech (independent speech, oratio recta) - here it takes the form of an emotionally rich and extremely faithfully reproduced monologue, where Władek presents his reasons and a subjective assessment of his past life [Schütze 2008a: 38]. The appearance of a detailed dramatic description of a situation is, as Schütze shows, most often associated with the culminating points in one's life in which essential turning points in the biography and life orientation take place [Schütze 1984: 90], and Władek is just on the verge of a great change.

It is worth looking at some parts of this situation from the point of view of a conversational analysis, whose findings contributed to the development of the autobiographical narrative interview method [see: Kaźmierska 2014]. We learn

17 In the only Polish edition [1976], the immigrant's diary is printed on pages 57-302. The letter from his sister Maria appears on page 282 (the first time he mentions going overseas), the fragment quoted above is on pages 283-284, and the journey to America is described on pages 288-289. The key immigration experience takes no more than last 12 pages (from the bottom of page 289 to the top of page 302 ) . 
from the author of the diary, that his brother tried to say something after Władek had told him: "You know best, my Pawel, what I have experienced here! You as well as the others were ashamed of me when I was in Łódź". According to the rules that people follow in their conversation, he was convinced that it was his turn to speak [Sacks, Schegloff, Jefferson 1974], the more so because he was called to speak by being accused ("you were ashamed of me"). An explanatory, contradictory or justifying interactional partner sequence would be a natural effect maintaining the social order - as Sacks and Schegloff explain: the appearance of an adjacency pair [Schegloff, Sacks 1973: 295-296]. One more time we find that Paweł really wanted to speak at that time, but he was not allowed to: "Wait, don't interrupt me". Such breach of the rules by not allowing someone to speak, which largely questions an interactive rule of reciprocity, usually requires corrective devices, which took the form of explanations provided by Władek himself. He tried to take his brother's perspective and explained that he was not angry because if he were Paweł, he would be ashamed of himself, too.

In the subsequent part Władek, clearly demonstrates how the Significant Others (mainly parents) systematically provided him with a "mirror reflection of his conviction that there is something wrong going on with him" [Schütze 2012: 424], constantly undermining the moral basis for cooperation (he is convinced that he had been cheated when they were running the bakery together), neglecting his expectations by constantly treating him as just an apprentice and ridiculing him in the eyes of candidates for his wife. Parents used different measures and a different set of rules for Władek (in contrast to how they treated the other sons and daughters). In his opinion, they did not give him what they gave in a natural way to his brothers (e.g. opportunities for education), and they did not support his actions. But in his view, his parents should support their children equally and fairly ${ }^{18}$. This vivid reproduction of the situation is evidence of the problematic nature of Władek's entire biography, which he wanted to put in front of the listeners and pass it on to potential readers. He had to deal with many painful experiences and an unjust image of himself in the eyes of others: his family were ashamed of him, he was derided and expelled from his property by his parents, he was ridiculed in front of girls, and the fact that his parents did not care about anything (we can assume: anything that was connected with him).

18 Certainly, responsibilities of parents towards children have undergone significant cultural transformations but concentrating only on Władek's life history and information collected from other members of his family, we can say that his parents really treated him differently. This was probably one of the most important reasons for his deepening distrust and a severe break in their relationship. 
This leads him to a final declaration that he "prefers to die there far away, even in misery, rather than remain here the laughing stock of my family".

To sum up, let us note once again that the sequence of events in Władek's life is of sinusoidal nature, where every attempt to recover or regain a precarious balance of everyday life is thwarted by bad fortune and inevitably leads to deeper and deeper plunging in chaos of everyday experience and painful loss of control over his own life. Of course, one can ask why his own decisions to stop working (leaving or abandoning his apprenticeship) are not treated here as independent and requires taking responsibility for this action, but as a manifestation of helplessness typical of an overwhelming experience of suffering. In the light of Władek Wiśniewski's life story presentation, it seems quite probable that firstly, as we could see, he resigned from work when a set of violations of moral and social orders went beyond the limit in his subjective hierarchy of values and could not be tolerated by him any longer (drunkenness, violence, waste, injustice). Secondly, he did not learn to deal with problems and to trust himself because no one (especially the Significant Others) believed in the meaning and purposefulness of his initiatives, ideas and actions [see: Schütze 2008a: 64]. In fact, his life-record reveals the process of growing disorder, which is ironically dynamited by the Significant Others, especially his parents who definitively and irrevocably "confirm his self-identification as a hopeless failure" [Berger, Luckmann 1991: 170] ${ }^{19}$. Władek often experiences peak phases of the process dynamics of trajectory of suffering, which are characterized by the collapse of the organization of everyday life and self-orientation [Schütze 2012: 429] related to an overwhelming sense of alienation, marginalization, an extreme loss of confidence in himself and others as well as an unbearable feeling of being cheated. This is accompanied by a sense of loss of meaning of life and lack of any hope that this situation would ever change.

\section{CONCLUSION}

Finally, let us look at "external" sources revealing the perspectives of other family members. They were gathered by Franciszek Jakubczak who visited the United States in 1972 to find the lost original materials analysed by Thomas and Znaniecki. Among other things, he tried to get more information about Władek's life and

19 There are many such fragments in which Władek shows dissonance between how he sees himself and how his closest ones perceive him (and others in general), for instance: "Although I very seldom played any tricks, I was always considered guilty and I cried much because of this. My mother and father almost never gave me such caresses and they gave my brothers and sisters. So, I often fled to solitude" [Thomas, Znaniecki 1919: 103]. 
therefore he was exchanging letters with some of his relatives. The results of his research were published at the end of the Polish edition of The Polish Peasant... Volume 3 [see: Jakubczak 1976: 314-321].

Franciszek Jakubczak quotes, for instance, a letter from sister Stefania and we learn from it that: - I am paraphrasing her words - out of many siblings, "the eagle-like" brothers, all but one "worked out fine" and "went up beyond their class", only Władek did not achieve anything and was called by his mother "a bane", and she also used to say that "she has sent him to the baker to make him somebody". While his unusually intelligent, well-read, smart and musically talented brothers became village mayors, teachers and merchants, he turned out to be someone who became a drunkard wandering around from town to town looking for work, "a vagrant", as his mother called him. And "a disgrace to the family" as Stefania adds [Jakubczak 1976: 315-316]. Perhaps Władek's niece (Ludwik's daughter) makes the most accurate diagnosis of his "situation" or position in the family and his reasons for emigration. Having listened to his cousin Florentyna's story, she writes in a letter to the above-mentioned Jakubczak:

Władysław was treated both by his parents as siblings with some sort of disdain, they blamed him for not learning well, that he is not aiming at the social position equal to his brothers' achievements. Supposedly, he was considered a romantic - in a pejorative meaning of the word - a person with an unstable nature, unable to act persistently and with great effort. I am curious - she continues - if in his records my uncle mentions this attitude of his family towards himself and if he acknowledges that this - at least to some extent - influenced his decision of emigration [Jakubczak 1976: 319].

Considering the whole organization of Władek Wiśniewski’s biography, the method of summarizing his own life in the homeland, giving his reasons for going to America, but also external images of his character, which diverged from the one kept in the minds of much of his family, we can propose a different interpretation of his biography. Emphasizing an analysis of biographical processes and Władek's own definitions and interpretations, we can see how much of his experience can be regarded as a trajectory of suffering, depriving him of the ability to control his own life and deepening his social isolation [Riemann, Schütze 1991; Schütze 2012]. This means that in his case the basic reason for going overseas cannot be reduced to economic-structural factors. It is essential to consider his need to free himself from the strangling, objectifying environment, his inability to develop his own internal spontaneity, his feeling of being stigmatized and thus increasing self-alienation and irritation towards everyday reality. His remedy to this is to escape, to become distant, to neutralize the influence of external compulsion, and finally to find meaning and moral foundations of existence. So, we may 
assume, that this is how Władek can think about his trip to America. He says: "Perhaps there, beyond the pond, I shall earn enough for my own bakery. Then I will come back, and if I don't earn, I won't come". Obviously, this statement can be interpreted as a reason for labour emigration, but it is primarily about setting oneself free from the exploitative power of parents, going one's own way, fulfilling oneself "far enough" so that the Significant Others could not interfere, evaluate, humiliate, comment, advise or manipulate.

\section{BIBLIOGRAPHY}

Berger Peter L., Thomas Luckmann. 1991. The social construction of reality. A treatise in the sociology of knowledge. London: Penguin Books.

Bertaux Daniel. 2012. Analiza pojedynczych przypadków (au cas par cas). In: Metoda biograficzna w socjologii, Antologia tekstów, Kaja Kaźmierska (ed.), 309-333. Kraków: Zakład Wydawniczy „Nomos”.

Czyżewski Marek. 1992. Uwagi o badaniach biograficznych. W: Bunty i stużebność uczonego: prof. Józef Chałasiński, L. Wojtczak (ed.), 93-100. Łódź: Wydawnictwo Uniwersytetu Łódzkiego.

Czyżewski Marek, Alicja Rokuszewska-Pawełek. 2016/1989-1990. Analiza autobiografii Rudolfa Hössa. W: Biografia i wojna. Metoda biograficzna w badaniu procesów społecznych, R. Dopierała, K. Waniek (eds.), 373-445. Łódź: Wydawnictwo Uniwersytetu Łódzkiego.

Duda-Dziewierz Krystyna. 1938. Wieś małopolska a emigracja amerykańska. Studium wsi Babica powiatu rzeszowskiego. Warszawa-Poznań: Polski Instytut Socjologiczny.

Glaser Barney G., Anselm L. Strauss. 1967. Discovery of grounded theory. Strategies for qualitative research. Chicago: Aldine.

Goffman Erving. 1990a. Stigma. Notes on the management of spoiled identity. London: Penguin Books.

Goffman Erving. 1990b. The presentation of self in everyday life. London: Penguin Books.

Gray Graham, Robert Miller (eds.). 2012. The evolution of European identities. Biographical approaches. London: Palgrave Macmillan.

Jakubczak Franciszek. 1976. Władysław Wiśniewski i jego rodzina. W: Chłop polski w Europie i Ameryce. Pamiętnik imigranta. Tom 3, 314-321. Warszawa: Ludowa Spółdzielnia Wydawnicza.

Kaźmierska Kaja, Andrzej Piotrowski, Katarzyna Waniek. 2011. "Biographical consequences of working abroad in the context of European mental space construction". Przeglad Socjologiczny 60(1): 139-158.

Kaźmierska Kaja. 2014. “An interview with professor Fritz Schütze: Biography and contribution to interpretative sociology". Qualitative Sociology Review 10(1): 284-359.

Kaźmierka Kaja. 2016. Wywiad narracyjny - technika i pojęcia analityczne. W: Biografia i wojna. Metoda biograficzna w badaniu procesów społecznych, R. Dopierała, K. Waniek (red.), 61-72. Łódź: Wydawnictwo Uniwersytetu Łódzkiego.

Labov Willam, Joshua Waletzky. 1967. Narrative analysis: Oral version of personal experience. In: Essays on the verbal and visual arts, J. Helm (ed.), 12-44. Seattle: University of Washington Press. 
Labov William. 1972. Language in the inner city. Studies in black English vernacular. Philadelphia: University of Pennsylvania Press.

Mead George H. 1934. Mind, self and society. Chicago: University of Chicago Press.

Piotrowski Andrzej. 2018. Paper given at a course of seminars devoted to "The centenary of the publication of the book The Polish Peasant in Europe and America by William Thomas and Florian Znaniecki (1918-1920)", Part I: "Methodology", held at Department of Economics and Sociology, University of Lodz, Poland, on April 12, 2018: https://www.youtube.com/ watch? $\mathrm{v}=\mathrm{NQ}$-aalM7YXE\&t=4841s.

Prawda Marek. 1989. Biograficzne odtwarzanie rzeczywistości (o koncepcji badań biograficznych Fritza Schütze). Studia Socjologiczne 4: 81-98.

Riemann Gerhard. 2007. "Suizidalität als Prozess - Eine Re-Analyse des Tagebuchs von Wallace Baker in Ruth Shonle Cavans «Suicide»", Zeitschrift für Qualitative Forschung 8(2): 287-327.

Riemann Gerhard, Fritz Schütze. 1991. "Trajectory” as a basic theoretical concept for analyzing suffering and disorderly social processes. In: Social organization and social processes. Essays in honor of Anselm Strauss, D.R. Maines (ed.), 333-358. New York: Aldine de Gruyter.

Rosenthal Gabriele. 2004. Biographical research. In: Qualitative research practice, C. Seale, G. Gobo, J.F. Gubrim, D. Silverman (eds.), 48-64. London: Sage Publications.

Treichel Bärbel, Birgit Schwelling. 2003. "Extended processes of biographical suffering and the allusive expression of deceit in an autobiographical narrative interview with a female migrant worker in Germany". Forum Qualitative Sozialforschung 3(5), http://www.qualitativeresearch.net/index.php/fqs/article/view/672/1453 [access: 18.11.2011].

Sacks Harvey, Emanuel Schegloff, Gail Jefferson. 1974. "A simplest systematics for the organization of turn-taking in conversation". Language 50: 696-735.

Schütze Fritz. 1980. Interaktionspostulate - am Beispiel literarischer Texte. Dostojewski, Kafka, Handke u.a. In: Literatur und Konversation. Sprachsoziologie und Pragmatik in der Literaturwissenschaft, E.W.B. Hess-Luttich (ed.), 72-94. Wiesbaden: Athenaion.

Schütze Fritz. 1981. Prozeßstrukturen des Lebensablaufs. In: Biographie in handlungswissenschaftlicher Perspektive. J. Matthes (ed.), 67-156. Nürnberg: Verlag der Nürnberger Forschungsvereinigung.

Schütze Fritz. 1983. "Biographieforschung und narratives Interview". Neue Praxis. Kritische Zeitschrift für Sozialarbeit und Sozialpädagogik 13(3): 283-293.

Schütze Fritz. 1984. Kognitiven Figuren des autobiographischen Stegreiferzälens. In: Biographie und Sozial Wirklichkeit, M. Kohli, R. Günther (eds.), 78-117. Stuttgart: Metzler.

Schütze Fritz. 1992. "Pressure and guilt: War experiences of a young German soldier and their biographical implications. Part 1". International Sociology 7(2): 187-208.

Schütze Fritz. 2008a. "Biography analysis on the empirical base of autobiographical narratives: how to analyse autobiographical narrative interviews. Part I", http://www.uni-magdeburg.de/ zsm/projekt/biographical/1/B2.1.pdf [access: 15.11.2011].

Schütze Fritz. 2008b. "Biography analysis on the empirical base of autobiographical narratives: How to analyse autobiographical narrative interviews. Part II", http://www.uni-magdeburg. de/zsm/projekt/biographical/1/B2.2.pdf [access: 15.11.2011].

Schütze Fritz. 2012. Trajektorie cierpienia jako przedmiot badań socjologii interpretatywnej. W: Metoda biograficzna w socjologii, Antologia tekstów, K. Kaźmierska (red.), 415-458. Kraków: Zakład Wydawniczy „Nomos”. 
Schütze Fritz. 2014. "Autobiographical accounts of war experiences. An outline for the analysis of topically focused autobiographical texts - using the example of the «Robert Rasmus» account in Studs Terkel's book, The Good War. Qualitative Sociology Review 10(1): 224-283.

Thomas William I., Florian Znaniecki. 1919. The Polish peasant in Europe and America. Monograph of an immigrant group. Volume 3: A life-record of an immigrant. Boston: The Gorham Press.

Urbańska Sylwia. 2015. Matka polka na odległość. Z doświadczeń migracyjnych robotnic 1989-2010. Toruń: Wydawnictwo Naukowe Uniwersytetu Mikołaja Kopernika.

Walaszek Adam. 2007. Migracje Europejczyków 1650-1914. Kraków: Wydawnictwo Uniwersytetu Jagiellońskiego

Waniek Katarzyna. 2011. Tożsamość europejska (?) - perspektywa bottom up. W: Integracja europejska a przemiany kulturowe w Europie, K. Kaźmierska, K. Waniek (red.), 63-80. Łódź: Wydawnictwo Uniwersytetu Łódzkiego.

Waniek Katarzyna. 2015. “《Ucieczka do...» jako istotna przyczyna mobilności w Europie”. Folia Sociologica 53: 31-50.

Katarzyna Waniek

\title{
EMIGRACJA WLADKA WIŚNIEWSKIEGO JAKO UCIECZKA - REINTERPRETACJA TRZECIEGO TOMU CHLOPA POLSKIEGO W EUROPIE I AMERYCE W ŚWIETLE METODY AUTOBIOGRAFICZNEGO WYWIADU NARRACYJNEGO
}

\author{
Streszczenie
}

Czytając życiorys Władka Wiśniewskiego zawarty w trzecim tomie „Chłopa polskiego w Europie i Ameryce" Thomasa i Znanieckiego i nie pomijając w pełni czynnika ekonomicznego, warto zwrócić uwagę na bardzo ciekawy i nierzadki powód wyjazdu z kraju ojczystego, to znaczy na „ucieczkę”. Jej współczesne warianty można umieścić na kontinuum rozciągającym się między „ucieczką od” a „ucieczką do”. Korzystając z narzędzi analitycznych opracowanych przez Fritza Schützego, które zostały stworzone znacznie później, ale w dużej mierze zainspirowane były osiąnnięciami Szkoły Chicago - w tym jej czołowych przedstawicieli jakim byli Thomas i Znaniecki - można wykazać, że głównym powodem opuszczenia kraju przez Władka było uwolnienie się z napiętych relacji rodzinnych. Były one nie tylko oparte na wyzysku i nieufności, ale też pełne hipokryzji i niesprawiedliwości. Tym samym chęć wyjazdu z domu wynikała w jego przypadku przede wszystkim z potrzeby zerwania z wizerunkiem własnej tożsamości w oczach znaczących Innych jako osoby niegodnej szacunku, pijaka i nieudacznika. Główna hipoteza tego artykułu (wyłaniająca się z analizy konstelacji wydarzeń w jego życiu) brzmi zatem: podstawową przyczyną, dla której Władek Wiśniewski opuścił swój kraj rodzinny i wyjechał do Ameryki nie były w pierwszym rzędzie motywy ekonomiczne, lecz splot okoliczności rozciągających się między „ucieczką od” a „ucieczka do”, choć przeważają te drugie.

Słowa kluczowe: „Chłop polski w Europie i Ameryce”, migracja, ucieczka, lingwistycznie ugruntowana analiza autobiografii, reinterpretacja. 